\title{
THE SERUM CHOLESTEROL LEVEL OF THE PREMATURELY BORN INFANT AND ITS MOTHER
}

\author{
By M. JAMES WHITELAW 1 \\ (From the Departments of Obstetrics and Gynecology of Parkland Hospital and the \\ Southwestern Medical College, Dallas, Texas)
}

(Received for publication October 6, 1947)

Although Virchow (1) in 1847 had shown that the milky material in the blood of pregnant women was fatty in nature, it was not until 1911, that Neumann and Hermann (2) first actually demonstrated an increased total blood cholesterol during pregnancy. Both free and ester cholesterol were found to be increased in plasma and serum by Slemons and Stander ( 3 ) and others ( 4 to 7 ). There is general agreement that the total cholesterol begins to rise early in the second trimester gradually reaching its peak at the eighth month, the average increase being approximately 25 per cent above normal.

In contrast to the high values found in the maternal circulation, it had been noted by Boyd and Wilson (8), Needham (9), Mayer (10), Schlossmann (11), and Muhlbock and Kaufmann (12), that the total cholesterol content of the fetal serum (or blood) was quite low. All except the first of these authors, therefore, have doubted the permeability of the human placenta to cholesterol.

Inasmuch as recent evidence suggests that cholesterol may be vital in steroid metabolism (13 to 16), it was decided in connection with related problems to investigate the cholesterol content of the serum of the premature infant and its mother. The author is not aware of any data in the literature on human subjects.

\section{METHOD OF STUDY}

All of the blood samples used in this study were obtained from patients in the delivery room at Parkland Hospital. There was no selection of cases, those reported being taken at random. Inasmuch as most of the patients entered the hospital in active labor, it was impossible to regulate the previous diet of the patient in order to control the length of time between the last meal and delivery. ${ }^{2}$

1 Present address : 412 W. Roosevelt St., Phoenix, Arizona.

2 Review of the literature by Weinhouse (27) in 1943 on the influence of diet on cholesterol levels indicates that alimentary hypercholesteremia after either ordinary
All newborns used in this study weighed under 2,500 grams. As soon as delivery was effected the umbilical cord was clamped and cut instead of waiting for the cord to stop pulsating in the orthodox manner. Fifteen cc. of blood were collected in a sterile tube from the placental end of the cord and allowed to clot. At the same time, $20 \mathrm{cc}$. of blood were drawn from the antecubital vein of the mother. Five cc. were reserved for a determination of the hematocrit reading, employing an isotonic anticoagulant. The remainder was allowed to clot and the serum after separation was refrigerated up to the time of the chemical analyses, which were in all cases started within 8 hours after delivery. Complete blood counts were made on the mother at the time of delivery.

The method used for determination of free and esterified cholesterol was that of Schoenheimer and Sperry (17) as modified by Sperry (18). It consists in principle of the precipitation of cholesterol with digitonin before and after saponification, after which the Liebermann-Burchard color reaction is used for the colorimetric determination, using a modified Duboscq colorimeter.

\section{RESULTS}

Table I shows the results obtained in the nine cases that have been studied. The total cholesterol of these prematures ranged from $51 \mathrm{mgs}$. per cent to $96 \mathrm{mgs}$. per cent with a mean of $71 \mathrm{mgs}$. per cent; whereas the mothers' values were $186 \mathrm{mgs}$. per cent to 383 mgs. per cent with a mean of 235 mgs. per cent. The free and combined fractions of cholesterol of the premature were rather constant, ranging from 25 per cent to 36 per cent, and 64 per cent to 75 per cent, respectively. The corresponding fractions for the mothers were 24 per cent to 39 per cent, and 61 per cent to 76 per cent. The averages of the partition for both mothers and immature infants are essentially identical. The lowest total cholesterol content ( $51 \mathrm{mgs}$. per cent) of the series was found in a baby weighing 2,268 grams, while the highest (96 mgs. per cent) was recorded in a newborn of only 1,270 grams.

meals or even meals containing considerable cholesterol has not been definitely proved. 
TABLE I

Serum cholesterol content of premature infants and mothers in nine cases

\begin{tabular}{|c|c|c|c|c|c|c|c|c|c|c|}
\hline & \multicolumn{10}{|c|}{ Serum cholesterol } \\
\hline & \multicolumn{6}{|c|}{ Fetal cord blood } & \multicolumn{4}{|c|}{ Mothers' blood } \\
\hline & & Sex & Total & Combined & Free & Combined & Total & Combined & Free & Combined \\
\hline $\begin{array}{l}1 . \\
2 . \\
3 .\end{array}$ & $\begin{array}{r}\text { sms. } \\
970 \\
1010 \\
1114\end{array}$ & $\begin{array}{l}\mathbf{F} \\
\mathbf{M} \\
\mathbf{F}\end{array}$ & $\begin{array}{c}\text { mgs. \% } \\
66.7 \\
69.0 \\
59.0\end{array}$ & $\begin{array}{c}\text { mgs. \% } \\
49.9 \\
48.0 \\
39.0\end{array}$ & $\begin{array}{c}\text { mgs. \% } \\
16.8 \\
21.0 \\
20.0\end{array}$ & $\begin{array}{l}\% \\
73 \\
70 \\
66\end{array}$ & $\begin{array}{c}\text { mgs. \% } \\
383 \\
202 \\
\text { No blood }\end{array}$ & \begin{tabular}{|c|} 
mgs. \% \\
294 \\
130 \\
No blood
\end{tabular} & $\begin{array}{c}\text { mgs. \% } \\
89 \\
72 \\
\text { No blood }\end{array}$ & $\begin{array}{c}\% \\
76 \\
64 \\
\text { No blood }\end{array}$ \\
\hline $\begin{array}{l}4 . \\
5 . \\
6 . \\
7 . \\
8 . \\
9 .\end{array}$ & $\begin{array}{l}1270 \\
1277 \\
1450 \\
2156 \\
2268 \\
2381\end{array}$ & $\begin{array}{l}\mathbf{M} \\
\mathbf{F} \\
\mathbf{F} \\
\mathbf{F} \\
\mathbf{F} \\
\mathbf{F}\end{array}$ & $\begin{array}{l}95.5 \\
67.2 \\
63.1 \\
90.1 \\
51.2 \\
73.4\end{array}$ & $\begin{array}{l}67.6 \\
48.1 \\
41.9 \\
67.6 \\
32.4 \\
50.9\end{array}$ & $\begin{array}{l}27.9 \\
19.1 \\
22.0 \\
22.5 \\
18.8 \\
22.5\end{array}$ & $\begin{array}{l}70 \\
71 \\
67 \\
75 \\
64 \\
69\end{array}$ & $\begin{array}{l}287 \\
204 \\
192 \\
186 \\
197 \\
228\end{array}$ & $\begin{array}{l}204 \\
147 \\
128 \\
130 \\
141 \\
139\end{array}$ & $\begin{array}{l}83 \\
57 \\
64 \\
56 \\
56 \\
89\end{array}$ & $\begin{array}{l}71 \\
72 \\
63 \\
69 \\
72 \\
61\end{array}$ \\
\hline \multicolumn{3}{|c|}{ Average } & 70.6 & 50.2 & 21.2 & 69.3 & 235.1 & 164.1 & 70.7 & 69.7 \\
\hline
\end{tabular}

\section{DISCUSSION}

It is noted that the relationship of free and esterified serum cholesterol to that of the total is remarkably constant, which confirms the findings obtained by Burger (19) Muhlbock and Kaufmann (12), Offenkrantz (20), and Smith and Marble (21).

It may also be noted that there is little, if any, change in cholesterol partition or absolute levels depending on the sex of the newborn. In addition it is seen that the serum cholesterol level of the immature infant is independent of its degree of prematurity and that it is for all purposes the same as that of a full term infant.

It appears from these data that during the last $21 / 2$ months of fetal life there is a low serum cholesterol and that the serum cholesterol of the mother bears no relationship to that of the fetus, so that permeability of the placenta to maternal cholesterol must be seriously questioned.

It has been noted by Gage (22), Mendel (23), and Baumann (24) that fat stained with Sudan III is stored when fed to pregnant animals. The fetus, however, shows no red color in its fatty tissue, thereby casting doubt on the transmission of fat across the membrane. In contrast to this work Boyd and Wilson (8) have shown very small arteriovenous differences in the lipid content of cord blood which they believe are due to transmission of small quantities of lipids to the fetus.

There has been no attempt made by any worker to explain the low cholesterol values found in the newborn. It might be pointed out that after birth during the first 4 days of life there is a marked increase in total cholesterol, the values ranging from 90 to 140 mgs. per cent. After this the value remains fairly constant. Sperry (25) found the average value of total cholesterol from the fourth day on to be 133 mgs. per cent. This rise in cholesterol is converse to the estrogenic titer in the newborn which falls very rapidly immediately after birth, its only source having been the maternal blood stream. It has been reported by both Burger (19) and Muhlbock and Kaufmann (12) that there is a rise in the cholesterol content of the maternal blood during the puerperium, and that levels may exceed those reached during the eighth month. It has been noted by Levin (26) that large doses of stilbesterol markedly depress the cholesterol content of the blood plasma as well as that of the adrenals.

It was the author's observation (unpublished data) that the adrenals of the premature newborn have a markedly lowered cholesterol content. It may therefore be suggested that perhaps this lowered blood cholesterol of the newborn may be indirectly connected with the action of the estrogenic hormones. Further investigation of the validity of this hypothesis is in progress.

\section{SUM MARY}

1. The serum cholesterol values of the immature infant are the same as those of the fullterm infants. 
2. The absolute levels and partition of serum cholesterol do not vary with degree of prematurity.

3. The cholesterol levels of mother and infant bear no relationship to each other.

4. The free and ester fraction of cholesterol are found to be approximately 30 per cent and 70 per cent, respectively, in both the fetal and maternal serum.

5. It is suggested that the low cholesterol value obtained in the serum of the prematurely born infant and term newborn may be due to the depressant action of estrogenic hormones.

\section{BIBLIOGRAPHY}

1. Virchow, R., Bemerkungen über Fettbildung im Thierischen Körper und Pathologische Resorption. Arch. f. Path. Anat., 1847, 1, 94.

2. Neumann, J., and Herrmann, E., Biologische Studien über die weibliche Keimdrüse. Wien. klin. Wchnschr., 1911, 24, 411.

3. Slemons, J. M., and Stander, H. J., Lipoids of maternal and fetal blood at conclusion of labor. Bull. Johns Hopkins Hosp., 1923, 34, 7.

4. Fahrig, C., and Wacker, L., Vergleichende Untersuchungen über den Lipoidkomplex des Blutserums bei essentieller Hypertension, Muskelarbeit, Hunger, Schwangerschaft und Nahrungsaufnahme. Klin. Wchnschr., 1932, 11, 886.

5. Hellmuth, K., Beiträge zur Biologie des Neugeborenen. II. Mitteilung. Arch. f. Gynäk., 1926, 127, 293.

6. Kaufmann, C., and Muhlbock, O., ther Cholesterinbilanzen in der Schwangerschaft und im Wochenbett. Ztschr. f. d. ges. exper. Med., 1933, 89, 200.

7. Pribram, E. E., Cholesterol metabolism in pregnancy and childbirth. Arch. f. Gynäk., 1923, 119, 57.

8. Boyd, E. M., and Wilson, K. J., Exchange of lipids in umbilical circulation at birth. J. Clin. Invest., $1935,14,7$.

9. Needham, Joseph, Chemical Embryology, Vol. III, p. 1521. Cambridge Univ. Press, London, 1931.

10. Mayer, A., Biologie der Placenta; physiologischer Teil. Arch. f. Gynäk., 1929, 137, 1.

11. Schlossmann, H., Der Stoffaustausch zwischen Mutter und Frunct durch die Placenta. Ergebn. d. Physiol., 1932, 34, 741.
12. Muhlbock, O., and Kaufmann, C., Der Cholesteringehalt im Blut bei gesunden Frauen. Ztschr. f. d. ges. Exper. Med., 1938, 102, 461.

13. Block, K., Biological conversion of cholesterol to pregnanediol. J. Biol. Chem., 1945, 157, 661.

14. Block, K., Berg, B. N., and Rittenberg, D., Biological conversion of cholesterol to cholic acid. J. Biol. Chem., 1943, 149, 511.

15. Sayers, G., Sayers, M. A., Liang, T. Y., and Long, C. N. H., Effect of pituitary adrenotropic hormone on cholesterol and ascorbic acid content of adrenal of rat and guinea pig. Endocrinology, 1946, 38, 1.

16. Sayers, G., Liang, T. Y., and Long, C. N. H., Cholesterol and ascorbic acid content of adrenal, liver, brain, and plasma following hemorrhage. Endocrinology, 1945, 37, 96.

17. Schoenheimer, R., and Sperry, W. M., Micromethod for determination of free and combined cholesterol. J.' Biol. Chem., 1934, 106, 745.

18. Sperry, W. M., Micromethod for determination of total and free cholesterol. Am. J. Clin. Path. (Tech. Supp.), 1938, $2,91$.

19. Burger, M., Der Cholesterinhaushalt beim Menschen. Ergebn. d. inn Med. u. Kinderh., 1928, 34, 583.

20. Offenkrantz, F. M., Serum cholesterol fluctuations during menstrual cycle. Am. J. Clin. Path., 1938, 8, 536.

21. Smith, R. M., and Marble, A., Colorimetric determination of free and combined cholesterol. J. Biol. Chem., 1937, 117, 673.

22. Gage, S. H., and Gage, S. P., Coloration of the milk in lactating animals and staining of the growing adipose tissue in the suckling young. Anat. Record, 1908, 3, 203.

23. Mendel, L. B., and Daniels, A. L., The behavior of fat-soluble dyes and stained fat in the animal organism. J. Biol. Chem., 1912, 13, 71.

24. Baumann, E. J., and Holly, O. M., Cholesterol and phosphatide in some tissues of pregnant and nonpregnant rabbits. Am. J. Physiol., 1926, 75, 633.

25. Sperry, W. M., Relationship between total and free cholesterol in human blood serum. J. Biol. Chem., 1936, 114, 125.

26. Levin, L., Effect of low pressure, low temperature, diethyl stilbesterol administration, and starvation on the cholesterol content of serum and of adrenal glands. Fed. Proc., 1945, 4, 97.

27. Weinhouse, S., Blood cholesterol. Arch. Path., 1943, $35,438$. 